\title{
nowe \\ The role of quasi-stationary waves in annual cycle in mid- latitude stratospheric and mesospheric ozone in 2011-2020
}

\author{
Chenning Zhang ${ }^{1}$, Oleksandr Evtushevsky ${ }^{2}$, Gennadi Milinevsky ${ }^{1,2,3, *}$, Yulia Andrienko ${ }^{2}$, Valerii Shulga ${ }^{1,4, *}$, Wei \\ Han ${ }^{1}$, and Yu Shi ${ }^{1}$
}

International Center of Future Science, College of Physics, Jilin University, Changchun 130012, China; zhangcn19@mails.jlu.edu.cn (C.Z.); shulga@rian.kharkov.ua (V.S.); whan@jlu.edu.cn (W.H.); gmilin@univ.kiev.ua (G.M.); shiyu18@mails.jlu.edu.cn (Y.S.)

2 Physics Faculty, Taras Shevchenko National University of Kyiv, 01601 Kyiv, Ukraine; evtush@univ.kiev.ua (O.E.); andrienko.yu@univ.kiev.ua (Y.A.)

3 Department of Atmosphere Physics and Geospace, National Antarctic Scientific Center, 01601 Kyiv, Ukraine

4 Department of Millimeter Radio Astronomy, Institute of Radio Astronomy, National Academy of Sciences of Ukraine, 61002 Kharkiv, Ukraine

* Correspondence: gmilin@univ.kiev.ua (G.M.); shulga@rian.kharkov.ua (V.S.); Tel.: +38-050-3525498 (G.M.); $+38-050-3004517$ (V.S.)

\begin{abstract}
The purpose of this work is to study quasi-stationary wave structure in the mid-latitude stratosphere and mesosphere $\left(40-50^{\circ} \mathrm{N}\right)$ and its role in the formation of the annual ozone cycle. Geopotential height and ozone from Aura MLS data are used and winter climatology for JanuaryFebruary 2011-2020 is considered. More closely examined is the 10-degree longitude segment centered on Longfengshan Brewer station, China, and located in the region of the Aleutian Low influence associated with the quasi-stationary zonal maximum of total ozone. Annual and semiannual oscillations in ozone were compared using units of ozone volume mixing ratio and concentration, as well as changes in ozone peak altitude and in time series of ozone at individual pressure levels between $316 \mathrm{hPa}(9 \mathrm{~km})$ and $0.001 \mathrm{hPa}(96 \mathrm{~km})$. The ozone maximum in the vertical profile is higher in volume mixing ratio (VMR) values than in concentration by about $15 \mathrm{~km}(5 \mathrm{~km})$ in the stratosphere (mesosphere), in consistency with some previous studies. We found that the properties of the annual cycle are better resolved in the altitude range of the main ozone maximum: middle-upper stratosphere in VMR and lower stratosphere in concentration. Both approaches reveal SAO/AO-related changes in the of ozone peak altitudes in a range of 4-6 km during the year. In the lower-stratospheric ozone of the Longfengshan domain, an earlier development of the annual cycle takes place with a maximum in February and a minimum in August compared to spring and autumn, respectively, in zonal means. This is presumably due to the higher rate of dynamical ozone accumulation in the region of the quasi-stationary zonal ozone maximum. The "no-annual-cycle" transition layers are found in the stratosphere and mesosphere. These layers with undisturbed ozone volume mixing ratio throughout the year are of interest for more detailed future study.
\end{abstract}

Keywords: quasi-stationary wave, stratosphere, mesosphere, westward phase tilt, geopotential height, ozone, annual and semi-annual oscillation.

\section{Introduction}

Quasi-stationary wave (QSW) in the atmosphere is known to be responsible for the formation of fairly stable planetary-scale anomalies in atmospheric variables and in the composition of the atmosphere (temperature, wind, sea level pressure, ozone, water vapor etc.) [1-3]. The QSWs originate in the troposphere from orographic and thermal sources [4] and penetrate upward into the stratosphere and mesosphere [1,2,5]. An 
important property of QSW is the westward phase tilt with altitude associated with the vertical propagation of stationary planetary waves [6,7]. The longest QSWs with zonal wave numbers $m=1$ and $m=2$ cause zonal asymmetry in the atmosphere and contribute to the appearance of regional weather anomalies in the troposphere with cold or warm air masses, with abundance or lack of precipitation $[3,8]$.

In the stratosphere, the QSW influence leads to zonal asymmetry of mid-latitude and polar ozone, temperature and zonal wind in winter and spring [1,2,7]. Ozone, in turn, can affect surface ultraviolet radiation [9-11], and, due to downward propagation of stratospheric anomalies and their large zonal asymmetry, surface weather anomalies often appear in the midlatitudes [8]. Studying the effects of stationary waves on total ozone, ultraviolet radiation and weather is therefore very important $[12,13]$. In the mesosphere, QSW contributes to changes in the circulation patterns, as well as to the variability and decadal trends in ozone and temperature $[5,14,15]$. Generally, the QSWs between the troposphere and mesosphere play a significant role in the longitudinal distribution of atmospheric parameters, establishing their regional distinctions.

Hood and Zaff [7] analyzed the QSW structure using early ozone data of 1979-1991 from TOMS Nimbus 7 satellite and geopotential height Z in 1979-1993 from reanalysis data. It has been shown that in the Northern Hemisphere (NH) in January ozone trends at $50^{\circ} \mathrm{N}$ are longitude-depended and inversely correlated with zonal anomalies in geopotential height Z. Due to the dominance of quasi-stationary wave 1 (QSW1), steady zonal asymmetry in the climatological ozone distributions over the NH exists [7,16-18]. As known, QSW1 can modulate the longitudinal distribution of total ozone column (TOC) (i) through the tropopause effect above the tropospheric pressure systems [7], (ii) by zonal asymmetry in the Brewer-Dobson circulation (BDC) in the stratosphere [2,19] and (iii) due to stratospheric polar vortex displacement relative to the pole [20,21]. Climatologically, the zonal TOC maximum and minimum are located in the North Pacific - East Asia and in the North Atlantic - Europe, in accordance with the locations of the main atmospheric centers of action with low and high surface pressure, respectively [7].

Since the anomalies of the tropospheric and stratospheric circulation are different in their seasonal changes, the climatological annual cycle (AC) in TOC can also be regionally different. In the zonal means, the annual TOC maximum (March-April) in the $\mathrm{NH}$ extratropics lags behind the tropospheric wave activity maximum (January) by about 3 months [22]. The time lag reflects the additional time for the tropical ozone-rich air involved in the BDC due to wave activity, to reach the extratropics. Taking into account the zonal asymmetry, $\mathrm{AC}$ has a maximum in February and a minimum in August in region of zonal TOC maximum [23] that is 2-3 months earlier than in the region of the zonal TOC minimum: April and October-November, respectively [24].

Most previous works, where the ozone seasonality was determined, used zonal mean [22,25-29], local [24,30,31] or regional [23,24,32,33] ozone data. The monthlongitude dependence of total ozone in zone $50-60^{\circ} \mathrm{N}$ has been presented by Zou et al. [34] (their Fig. 1). Statistically, this dependence was analyzed using monthly climatology of the annual TOC cycles along the zone $40-60^{\circ} \mathrm{N}$ with a $30^{\circ}$-step in longitude [35]. It has 
been shown that the AC development in East Asia $\left(120-150^{\circ} \mathrm{E}\right.$, zonal TOC maximum) occurs 2 to 3 months earlier than in East Atlantic $\left(0-30^{\circ} \mathrm{W}\right.$, zonal TOC minimum). This means that, similarly to zonal asymmetry in both the TOC distribution and the decadal TOC trends $[7,16,18,34,36]$, the annual TOC cycle in the $\mathrm{NH}$ mid-latitudes is also longitudinally dependent and is modulated by the QSW structure.

Due to the importance of QSW activity in changes in regional temperature, ozone and climate $[3,7,8,14]$, continuous monitoring of QSWs is required to detect their possible deviations in phase and amplitude relative to climatology. In this work, we present the QSW climatology 2011-2020 in its vertical changes between the troposphere and mesosphere in the NH mid-latitudes. Based on the Aura Microwave Limb Sounder (MLS) satellite data, the geopotential height $\mathrm{Z}$ and ozone volume mixing ratio and concentration are analyzed. Section 2 briefly describes the data and the analysis method. In Section 3, the QSW climatologies are presented. Annual cycles in stratospheric and mesospheric ozone are compared in Section 4. A summary of the results is given in Section 5.

\section{Data and analysis method}

The Aura MLS data on geopotential height $\mathrm{Z}$ and ozone volume mixing ratio are used from the NASA website [37-40]. The monthly means of January-February are averaged over the last decade of 2011-2020 and along the zone $40-50^{\circ} \mathrm{N}$, covering North China and Ukraine and influenced by the main atmospheric centers of actions in the $\mathrm{NH}$ (Fig. 1a). Regional anomalies in total ozone, temperature and carbon monoxide over Eastern Europe and Ukraine have been analyzed previously [35,41,42] and we focus here on East Asia and North China. Particularly, the Longfengshan segment of longitudes $122-132^{\circ} \mathrm{E}$ (light vertical strip in Fig. 1a) is chosen.

The two winter months, January-February, are at the annual maximum of planetary wave activity (December-February) with a peak in January [7,22]. On the other hand, total ozone maximum at Longfengshan is observed in February (Fig. 1b) and, by Coldewey-Egbers et al. [29], total ozone maximum in zonal mean at $40-55^{\circ} \mathrm{N}$ occurs in February-March.

We follow the analysis method by Hood and Zaff [7] and first we present the QSW structures by creating the climatological longitudinal distributions of $Z$ and ozone at 10 pressure levels (Section 3). Then, following the method [35], regional annual cycles in stratospheric and mesospheric ozone are compared (Section 4). In particular, we focus on the analysis of the annual cycles in ozone in the Longfengshan region, China $\left(128^{\circ} \mathrm{E}\right.$, $45^{\circ} \mathrm{N}$; black circle in Fig. 1a), which is under influence of the Aleutian Low (AL). Quasistationary anomaly in the AL sea level pressure in winter is located in North Pacific around $180^{\circ} \mathrm{E}$. Due to the QSW westward phase tilt with altitude, the related low Z anomaly in the lower stratosphere shifts to East Asia [7] and covers the study region in North China (AL and Longfengshan domain in Fig. 1a). This can be seen from the deviation of the $Z 9000$ isoline towards the subtropics around $120^{\circ} \mathrm{E}$ and from the intrusion of the low Z levels Z8600 into the zone $40-50^{\circ} \mathrm{N}$ (solid curves in Fig. 1a). 


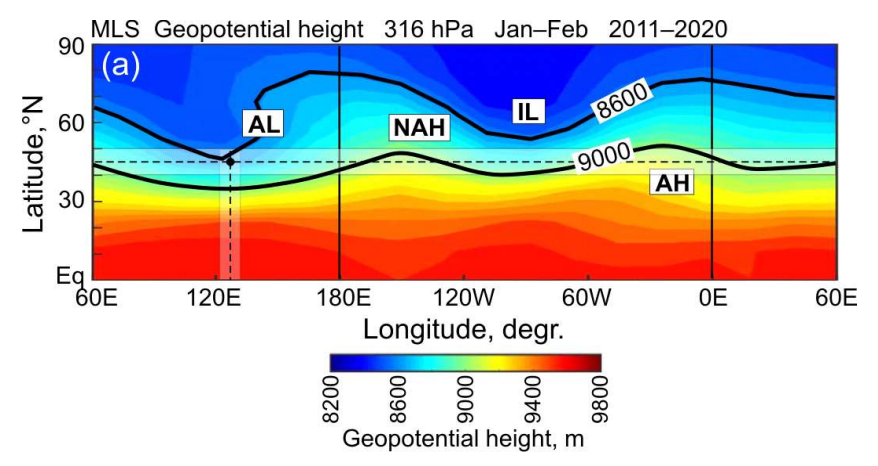

(b) WOUDC Longfengshan total ozone 2011-2020

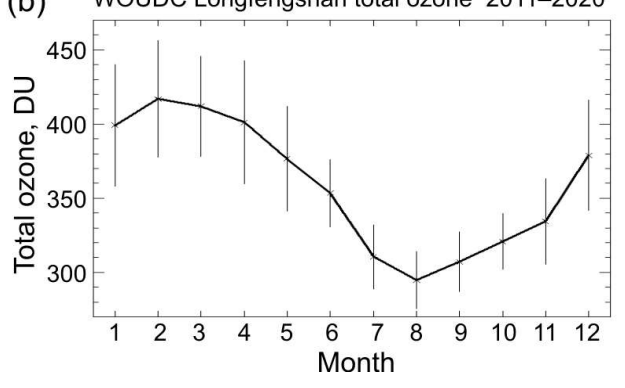

Figure 1. (a) Climatological geopotential height in the northern Hemisphere at $316 \mathrm{hPa}$ from the Aura MLS data averaged over January-February 2011-2020. Light stripes indicate zone $\left(40-50^{\circ} \mathrm{N}\right)$ and longitude segment $\left(122-132^{\circ} \mathrm{E}\right)$, which are centered at Longfengshan, China $\left(45^{\circ} \mathrm{N}, 128^{\circ} \mathrm{E}\right.$; dashed lines and black circle) and analyzed with respect to the QSW structure and ozone annual cycle. Solid curves Z8600 and Z9000 display zonal wave 2 in the QSW structure. The main atmospheric centers of action are indicated: AL is Aleutian Low, IL is Icelandic Low, NAH is North American High, and AH is Azores High. (b) Monthly mean total ozone with standard deviations as observed at Longfengshan in 2011-2020 (except for 2014 - 2015); from the WOUDC data.

The pressure level of $316 \mathrm{hPa}$, shown in Fig. 1a, lies near the tropopause of the $\mathrm{NH}$ mid-latitudes in winter $(8-9 \mathrm{~km}$; [43]). The AL is climatologically associated with a zonal minimum in the tropopause height and maximum in total ozone [7]. Note that the two pairs of lows and highs (AL-IL and NAH-AH) form zonal wave 2 in the mid-latitude QSW structure (Fig. 1a). Azores High is subtropical anticyclone (AH in Fig. 1a), which is relatively weak in winter, however, influences the mid-latitude stratosphere because of systematical poleward shift with altitude relative to its lower-tropospheric counterpart $[44,45]$.

The weather station in Longfengshan, China, is equipped with Brewer spectrophotometer since 1993, WOUDC station ID 326. Monthly mean total ozone with standard deviations from observations at the Longfengshan station in 2011-2020 is shown in Figure $1 b$.

To analyze quasi-stationary wave structure in the mid-latitude stratosphere and mesosphere, we used the data on ozone, geopotential heights $(Z)$ and temperature from the Microwave Limb Sounder on the Aura satellite (Aura MLS) [37-40]. We used 10 pressure levels located in the troposphere, stratosphere and mesosphere: 825, 316, 100, 
$26,10,3.16,1,0.1,0.01$ and $0.001 \mathrm{hPa}(2-96 \mathrm{~km})$ with a vertical resolution of $\sim 2 \mathrm{~km}$ in the stratosphere and $\sim 6 \mathrm{~km}$ in the mesosphere. However, analysis of data was provided for pressure range 261-0.02 hPa [37]. When selecting Aura MLS data for comparison, unless otherwise specified, we use the longitude range $\pm 10^{\circ}$ for the local longitude coordinates and $\pm 2.5^{\circ}$ for the latitude coordinates.

We also compare the ozone annual cycle using volume mixing ratio (VMR) in parts per million by volume (ppmv) and concentrations in molecules $\cdot \mathrm{cm}^{-3}$. For analysis the ozone VMR values in ppmv unit were converted to ozone concentrations. If VMR represents the relative volume content of ozone, then the concentration shows the actual mass of ozone per unit volume. Under conditions of decreasing atmospheric pressure with altitude, VMR and concentration show different vertical ozone profiles (e.g. [46]. In this work, we explore for the first time how the annual ozone cycle in the stratosphere and mesosphere manifests itself in each of the two units.

\section{QSW structure}

Figure 2a shows vertical changes in the QSW structure in geopotential height between $825 \mathrm{hPa}$ and $0.001 \mathrm{hPa}$. There is a successive vertical transition between the troposphere and the lower stratosphere from QSW with zonal wave number $m=2$ (QSW2) to $m=1$ (QSW1) (the four lower curves at pressure levels 825, 316, $100 \mathrm{hPa}$ and $26 \mathrm{hPa}$ in Fig. 2a). The positive (negative) deviations from zonal mean indicated at the QSW peaks by red (blue) bars show a vertical modification of QSW2 to QSW1. QSW1 remains the dominant wave component also higher up to $0.1 \mathrm{hPa}(64 \mathrm{~km})$ and the $\mathrm{Z}$ anomaly peaks at the stratopause (422 $\mathrm{m}$ at $1 \mathrm{hPa}$ in Fig. 2a).

There is a clear westward phase tilt in the QSW structure between the lower troposphere and lower mesosphere $(825 \mathrm{hPa}$ and $0.1 \mathrm{hPa}$ in Fig. 2a). On the whole, westward shifts are about $150^{\circ}$ for QSW maximum $\left(120^{\circ} \mathrm{W}-180^{\circ} \mathrm{E}-90^{\circ} \mathrm{E}\right.$, red dotted line in Fig. 2a) and about $270^{\circ}$ for QSW minimum $\left(160^{\circ} \mathrm{E}-0^{\circ} \mathrm{E}-110^{\circ} \mathrm{W}\right.$, blue dotted lines in Fig. 2a).

Both properties of the vertical wave modification (QSW2 to QSW1 and westward phase tilt) are in correspondence with the QSW theory and observations: the longest waves are only able to penetrate from the troposphere into the stratosphere and their propagation in the westerly flow is accompanied be a westward phase tilt $[4,6,7]$. As shown by dotted lines in Fig. 2a, climatology 2011-2020 suggests that the source regions for the upper-level QSW extremes are projected to $\sim 160^{\circ} \mathrm{E}$ (minimum) and $\sim 120^{\circ} \mathrm{W}$ (maximum) in the lower troposphere. These longitudes correspond to the Aleutian Low and North American High regions (AL and NAH, respectively, in Fig. 2a). Due to westward phase tilt, the main stratospheric QSW ridge in Fig. 2a turns out to be located above the AL tropospheric anomaly and therefore assigned to the Aleutian anticyclone $[44,47,48]$. However, it is clearly associated with the NAH anomaly in the troposphere (red dotted line and $\mathrm{Z}$ anomaly at $120^{\circ} \mathrm{W}, 825 \mathrm{hPa}$, in Fig. 2a). Similar location of the main QSW ridge in the winter stratosphere follows from 10-year climatologies of 1985$1994\left(135^{\circ} \mathrm{W}, 56^{\circ} \mathrm{N}, 10 \mathrm{hPa}\right.$; ECMWF composite) in [44] and 2001-2010 (150 ${ }^{\circ} \mathrm{W}, 60^{\circ} \mathrm{N}, 20$ 
$\mathrm{km}$; ERA Interim data) in [2]. Although the association between Aleutian anticyclone in the stratosphere and NAH in the troposphere can be traced, for example, from the results $[2,44]$, it has not been specifically noted previously. In the stratopause - lower mesosphere region ( $1 \mathrm{hPa}$ and $0.1 \mathrm{hPa}$ in Fig. 2a), the QSW ridge (trough) extends predominantly to the eastern (western) hemisphere.
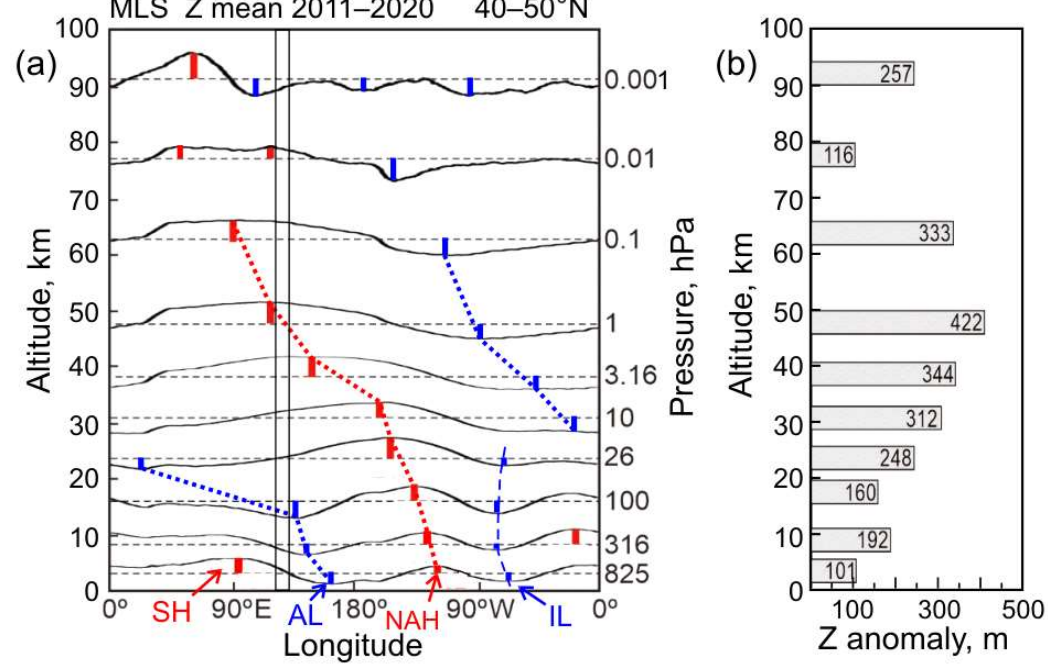

Figure 2. (a) Longitudinal distribution of geopotential height at 10 pressure levels between 2 and $96 \mathrm{~km}$. Averaging was made for January-February 2011-2020 in the zone $40-50^{\circ} \mathrm{N}$. Vertical red (blue) bars indicate maximum positive (minimum negative) $Z$ anomalies relative to the mean level. Vertical lines at $122-132^{\circ} \mathrm{E}$ show the Longfengshan region, China, being analyzed for the annual ozone cycle. AL and IL are Aleutian and Icelandic Lows, NAH and SH are North American and Siberian Highs. (b) Dependence of the maximum positive $\mathrm{Z}$ anomalies on the altitude.

The positive $\mathrm{Z}$ anomalies in the troposphere at $\sim 90^{\circ} \mathrm{E}$ (Siberian High region) and $\sim 70^{\circ} \mathrm{W}$ (Icelandic Low region) associated with QSW2 decay rapidly with height (SH and IL, respectively, in Fig. 2a). They do not make a significant contribution to the dominant structure of the QSW1 type in the middle-upper stratosphere and lower mesosphere. However, it is possible, that IL is partially involved in the formation of the QSW minimum in the stratosphere (dashed blue line in Fig. 2a). The IL center is located at high latitudes at about $60^{\circ} \mathrm{N}$ and it can spread up equatorward to latitudes of $40-50^{\circ} \mathrm{N}$, but with reduced intensity [49]. This explains its small effect on the QSW structure analyzed in this work. The SH anomaly in Central Asia is quite strong in the troposphere (SH in Fig. 2a), but has a limited vertical extent [50] and is not detected above the tropopause ( $316 \mathrm{hPa}$ and higher in Fig. 2a). Longitudinal distribution of $\mathrm{Z}$ anomalies at $0.01 \mathrm{hPa}$ and $0.001 \mathrm{hPa}$ (upper mesosphere - mesopause region) consists of small-scale wave component and looks uncoupled with prevailing QSW1 structure between $10 \mathrm{hPa}$ and $0.1 \mathrm{hPa}$ (Fig. 2a). 
As seen in Fig. 2b, the QSW amplitude increases through the stratosphere, and the maximum $\mathrm{Z}$ anomaly of $422 \mathrm{~m}$ is reached in the stratopause region $(1 \mathrm{hPa}, \sim 50 \mathrm{~km})$. Similar vertical profiles of stationary waves in geopotential height in winter can be found in $[2,51,52]$. There is secondary maximum in $\mathrm{Z}$ anomaly in Fig. $2 \mathrm{~b}$ at $0.001 \mathrm{hPa}$. It is in consistency with additional internal wave forcing in the mesosphere that is meant to represent the in situ planetary wave generation in winter [53].
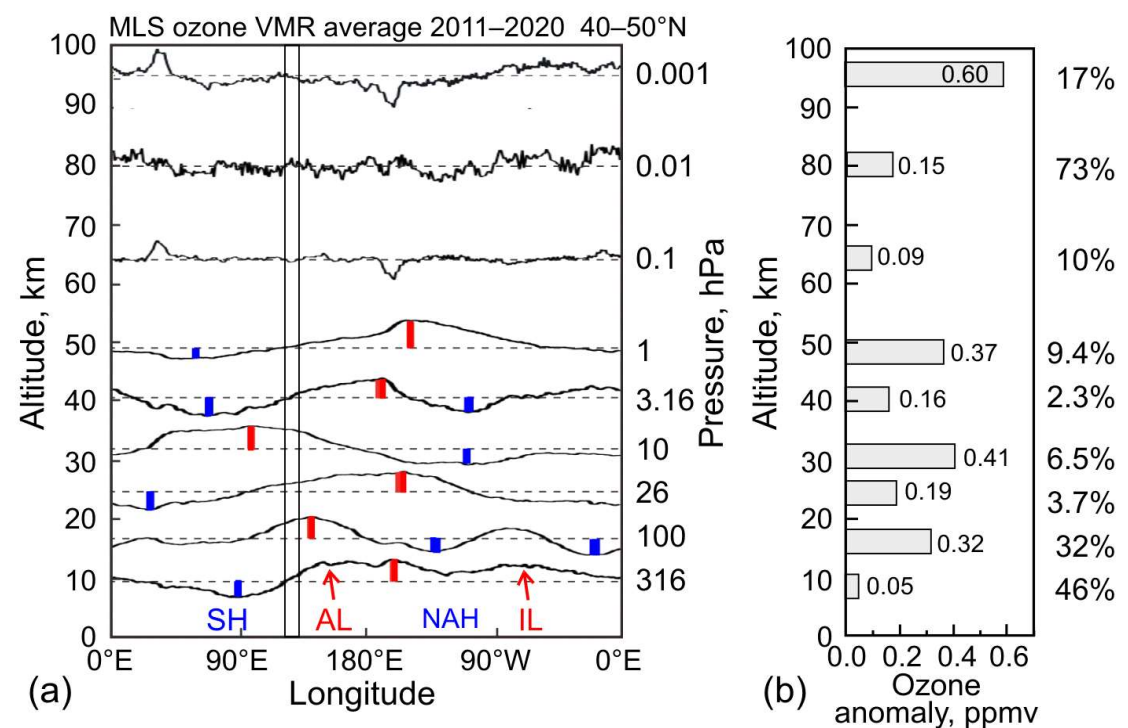

Figure 3. (a) Longitudinal distribution of ozone volume ratio at 9 pressure levels between 9 and $96 \mathrm{~km}$ in the stratosphere and mesosphere. Averaging was made for January-February 2011-2020 in zone 40-50N. Vertical red (blue) bars indicate maximum positive (minimum negative) VMR anomalies relative to the zonal mean. Red arrows show ozone maxima over AL and IL. Vertical lines at $122-132^{\circ} \mathrm{E}$ show the Longfengshan region, China, being analyzed for the annual ozone cycle. (b) Dependence of the maximum positive VMR anomalies on the altitude. Percentages relative to the zonal mean are indicated on the right. The two lower curves in Fig. 3a (at $316 \mathrm{hPa}$, or 9 $\mathrm{km}$, i.e. near the tropopause, and at $100 \mathrm{hPa}$, or $16 \mathrm{~km}$, in the lower stratosphere) have QSW2 structure anticorrelated with $\mathrm{Z}$ anomalies in Fig. 2a. The ozone maxima (minima) appear above tropospheric cyclones AL and IL (anticyclones SH and NAH). The SH effect, as noted above, has a limited vertical extent and is observed no higher than the tropopause level (9 km in Fig. 3a).

The $\mathrm{Z}$ anomaly peak in Fig. 2a $(422 \mathrm{~m}$ at $1 \mathrm{hPa})$ is in general consistency with that found from ODIN satellite data $\left(400-600 \mathrm{~m}, \sim 50 \mathrm{~km}, 60^{\circ} \mathrm{N}\right)$ in [2]. Higher values of anomalies in [2] are associated with an increase in wave disturbances at the polar vortex edge near $60^{\circ} \mathrm{N}$, where a strong zonal flow serves as a waveguide concentrating wave energy [6]. 
In contrast to Z anomalies (Fig. 2a), the QSW structure in ozone does not show a regular phase shift with altitude (Fig. 3a). Note that there is no westward phase tilt in the ozone VMR observed by ODIN satellite in 2001-2010 [2].

The relative contributions of the VMR anomalies to QSW2 are also the largest at the two lower levels (46\% and 32\% of zonal means, Fig. $3 \mathrm{~b}$ ). This means that (i) the QSW structure in total ozone is formed mainly by the lower stratospheric ozone under influence of the tropospheric centers of action and, as a result, (ii) an approximate inverse correlation holds between lower stratospheric geopotential height and total ozone in northern midlatitudes in winter [7]. The factors that determine the QSW structure above $100 \mathrm{hPa}$ need additional analysis with the creation of longitude-altitude sections using a higher vertical resolution than in Fig. $3 a$.

\section{Annual cycles}

We compare the time-altitude variations of ozone in VMR and concentration in the stratosphere (Fig. 4, left and right, respectively) and in the mesosphere (Fig. 5, left and right). It is shown how the vertical ozone profiles and their annual evolutions differ in each of the units used. The regions of the zonal ozone minimum $\left(5^{\circ} \mathrm{W}-5^{\circ} \mathrm{E}\right)$ and the zonal ozone maximum around Longfengshan $\left(122-132^{\circ} \mathrm{E}\right)$ in the stratosphere (Fig. 3a, curve at $100 \mathrm{hPa}$; see also [35]), as well as the zonal means of $40-50^{\circ} \mathrm{N}$ are shown (top, middle and bottom panels in Fig. 4 and Fig 5). Figure 6 presents the annual VMR variation at 9 selected pressure levels between $100 \mathrm{hPa}$ and $0.001 \mathrm{hPa}(16 \mathrm{~km}$ to $96 \mathrm{~km})$ in the Longfengshan region and in the zonal means (left and right, respectively).

In the stratosphere, the VMR maximum lies about $15 \mathrm{~km}$ higher than concentration maximum (dashed white curves in Fig. $4 \mathrm{a}-\mathrm{c}$ and $4 \mathrm{~d}-\mathrm{f}$ ). The $15-\mathrm{km}$ difference between the altitudes of ozone maximum in VMR and number density was observed also in the middle to high latitude stratosphere from the Improved Limb Atmospheric Spectrometer (ILAS)-II data in 2003 [46]. It follows from Fig. 4 that the midlatitude ozone maximum in winter is in the middle-upper stratosphere at about 30-45 km using VMR (left column) and in the lower stratosphere at about 16-28 km using concentration (right column). Taking into account the latitudinal difference, this is generally consistent with $\sim 35$ and $\sim 20 \mathrm{~km}$, respectively, in [46].

It should be noted that the semi-annual cycle is clearly seen at the VMR maximum (dashed white curves in Fig. $4 a-c$ ) and is barely visible at the same altitudes in concentration (solid white curves in Fig. 4d-f). On the contrary, annual cycle is clearly visible in concentration in the lower stratosphere (dashed black curves in Fig. 4d-f), where it is weakly expressed in VMR (solid white curves in Fig. 4a-c). These annual changes are commonly referred to as the annual oscillation (AO) and the semi-annual oscillation (SAO) (e.g. [54-56]. Note that we describe these annual changes by isolating and comparing altitude changes in peak or specific ozone VMR levels (curves in Fig. 4) as distinct from annual changes in ozone VMR itself at specific pressure levels (time series in Fig. 6). 

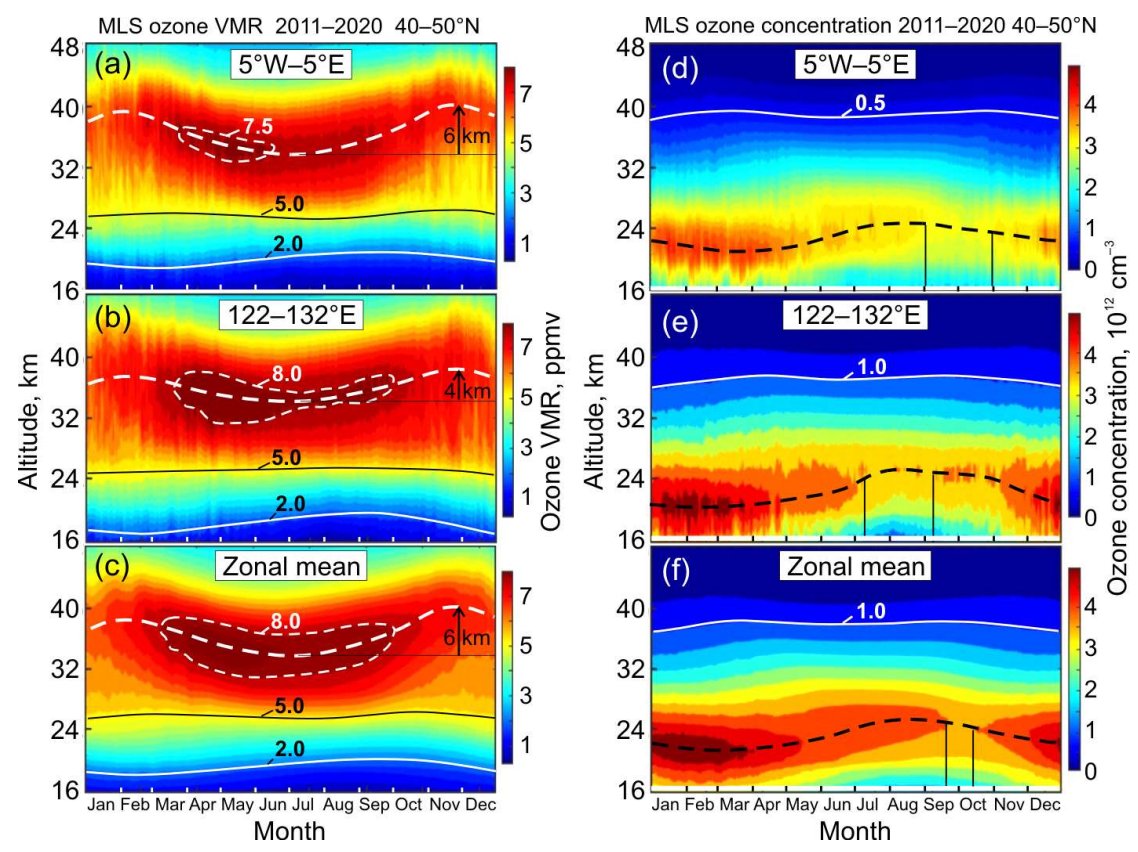

Figure 4. Annual variations in the stratospheric ozone between $16 \mathrm{~km}$ and $48 \mathrm{~km}$ (100-1 $\mathrm{hPa}$ ) in (left) volume mixing ratio and (right) concentration. Dashed (solid white) curves show the difference in annual ozone changes at the altitudes of ozone maximum (minimum) in each of the two units. In $(\mathrm{a}-\mathrm{c})$, dashed white contour outlines the maximum VMR and solid black curve shows "no-annual-cycle" level of about 5 ppmv at 24-26 km separating the annual and semi-annual cycles.

The use of the VMR unit reveals a "no-annual-cycle" boundary at about $25 \mathrm{~km}$ (solid black lines in Fig. $4 \mathrm{a}-\mathrm{c}$ ) between the weak AO in the lower stratosphere and the strong SAO in the middle-upper stratosphere. This boundary is most stable during the year in the Longfengshan region (solid black curve in Fig. $4 \mathrm{~b}$ and time series at $26 \mathrm{hPa}$, or $\sim 25 \mathrm{~km}$, in Fig. 6g). Dashed curves in Fig. 4 (left) indicate that strong SAO is formed due to large altitude oscillation of the VMR peak. The two highest (two lowest) altitudes occur in February and November (December-January and June-July) with oscillation range 4-6 km between of $34 \mathrm{~km}$ and $40 \mathrm{~km}$ (arrows in Fig. 4, left). Similar altitude difference is observed in $\mathrm{AO}$ in the lower-stratospheric concentration peaks (dashed black curves in Fig. 4, right).

The times and magnitudes of the VMR peaks are longitudinally dependent on the QSW structure in the stratosphere (Fig. 4a-c). The VMR peak in the region of the zonal ozone minimum occurs in spring and is shorter and less intense $(7.5 \mathrm{ppmv}$, dashed white contour in Fig. 4a) compared to the region of the zonal ozone maximum and zonal means. In the two latter cases, it lasts during spring-early autumn and is $0.5 \mathrm{ppmv}$ more intense (8.0 ppmv, dashed white contours in Fig. $4 \mathrm{~b}$ and $4 \mathrm{c})$. Nevertheless, it is common for all three cases in Fig. 4a-c that the VMR maximum occurs in summer, when the VMR peak decreases to the lowest altitudes of about $35 \mathrm{~km}$. 


\section{Discussion}

The summer ozone maximum in this stratospheric layer is formed due to photochemistry [23,57]. Ozone lifetime is $\sim 1$ day at $40 \mathrm{~km}$ [58] and the higher flux of shortwave solar radiation in summer determines higher photochemical production of ozone and the summer ozone maximum at these altitudes. Climatologically, the VMR maximum reaches 6-8 ppmv (Fig. 4a-c) that is consistent with 5-9 ppmv between $25 \mathrm{~km}$ and $45 \mathrm{~km}\left(50^{\circ} \mathrm{N}, 2002-2015\right)$ reported by Joshi et al. [56] from the Sounding of the Atmosphere using Broadband Emission Radiometry (SABER) satellite instrument data. Extended summer maximum with barely perceptible SAO is seen in the middle stratosphere at $10 \mathrm{hPa}$ (32 km; Fig. 6f and 6o), in consistency with the stratospheric ozone profiles from the GROMOS (GROund-based Millimeter-wave Ozone Spectrometer) microwave radiometer at Bern, Switzerland $\left(47^{\circ} \mathrm{N}, 8^{\circ} \mathrm{E}\right)$ described in [55]. In our interpretation, the $10-\mathrm{hPa}$ level is at the transition altitude between "no-annualcycle" level (solid black curves in Fig. 4, left) and the strong SAO altitudes (dashed white curves).

Upwards from the summer VMR maximum, the semi-annual oscillation becomes more distinct in the upper stratosphere (dashed curves in Fig. $4 a-c$ ) up to the stratopause (time series at $3 \mathrm{hPa}$ and $1 \mathrm{hPa}$ in Fig. 6d, e, m, n). An interesting vertical transition occurs between the middle $(10 \mathrm{hPa})$ and upper $(1-3 \mathrm{hPa})$ stratosphere: the summer VMR maximum (Fig. 6f and 6o) is replaced by the summer VMR minimum (Fig. 6e and 6n). Accordingly, prevailing photochemical production of ozone at 30-40 $\mathrm{km}[23,58]$ is replaced by catalytic ozone destruction, which peaks in the northern midlatitude upper stratosphere $(40-50 \mathrm{~km})$ during the summer months [59]. The summer ozone minimum in the upper stratosphere-stratopause region is explained by the temperature-dependent photochemistry, with the anti-correlation of ozone and temperature and higher ozone depletion of in warmer air conditions in summer [55]. Oscillated altitude of the VMR peak (dashed white curves in Fig. 4, left) shows the upper-stratospheric SAO with the two maxima appearing also in the VMR time series (curves for $3 \mathrm{hPa}$ and $1 \mathrm{hPa}$ in Fig. 6d, e, m, n). They occur in spring and autumn at 3 hPa (Fig. 6e and 6n) and approach to winter months at the beginning and at the end of the year at $1 \mathrm{hPa}$ (Fig. $6 \mathrm{~d}$ and $6 \mathrm{~m}$ ).

Downwards, the summer maximum is replaced by late-summer-autumn minimum in the lower stratosphere (Fig. 6h, i, q, r). The annual cycle in the regional VMR of the Longfengshan domain at $100 \mathrm{hPa}$ (Fig. 6i) is consistent with that in local total ozone climatology (Fig. 1b), showing a clear annual maximum (minimum) in February (August). This consistency confirms dominant contribution of the lower stratospheric ozone to total ozone column. 

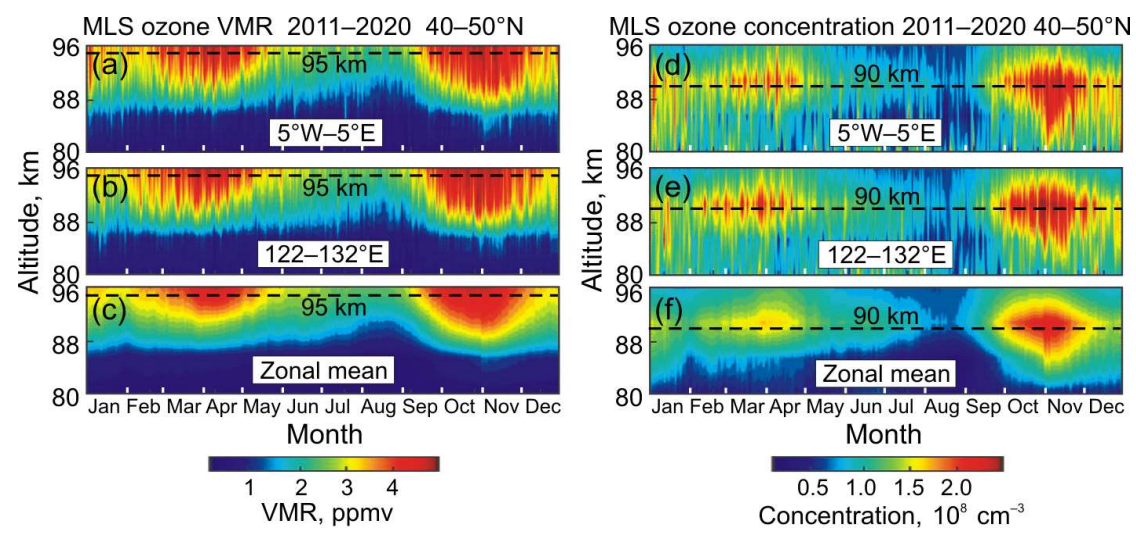

Figure 5. Semi-annual cycle in ozone at the altitudes of the secondary ozone maximum in the mesosphere between $80 \mathrm{~km}$ and $90 \mathrm{~km}(0.01-0.001 \mathrm{hPa})$ in (left) volume mixing ratio and (right) concentration.

On the other hand, earlier development of AO in Fig. 6i compared to zonal mean in Fig. 6r is evidence of the QSW structure influence. The specificity of AO here depends on the relationship between the rates of the processes of dynamical ozone accumulation (the larger effect of meridional circulation in autumn-winter) and photochemical relaxation (spring-summer) in the region of the quasi-stationary maximum of total ozone $[2,23,32,35]$. As a result, the AO extrema in the Longfengshan domain appear 2-3 months earlier than in the region of the zonal TOC minimum: April and OctoberNovember, respectively [24]. The zonal mean VMR in Fig. 6r has also the AO extrema, prolonged for the spring (maximum) and autumn (minimum) months.

In contrast to the timing of the VMR peak in the upper stratosphere (dashed white contours in Fig. 4, left), concentration better reflects regional difference in the time of annual concentration minimum in the lower stratosphere (vertical lines in Fig. 4, right). It can be seen that the earliest occurrence of annual minimum (summer months JulyAugust) occurs in the region of the zonal ozone maximum (Longfengshan segment in Fig. 4e). This AO evolution in the NH mid-latitude lower stratosphere is determined by the QSW structure in Fig. 3a (see also [23,32,35]). The two months later (SeptemberOctober), annual minimum is observed in region of zonal minimum and in zonal mean (Fig. 4d and 4f). Generally, this difference can be explained by the relationship between a rate of the process of photochemical ozone relaxation during late spring-summer following by dynamical ozone accumulation since late autumn and during winterspring [22,28,32].

In the mesosphere, "no-annual-cycle" conditions prevail at $0.1 \mathrm{hPa}$ and $0.01 \mathrm{hPa}(64$ $\mathrm{km}$ and $80 \mathrm{~km}$; Fig. 6b, c, k, 1). This is a layer with VMR of 0.2-0.9 ppmv. Note that Joshi et al. [56] have found 4-month oscillation in the VMR anomalies integrated between 60 $\mathrm{km}$ and $80 \mathrm{~km}$. This oscillation is not visible in our analysis of the separate pressure levels. The strong SAO appears in the mesopause region (Fig. 5 and Fig. 6a and 6j), where the secondary ozone maximum is located [56,60]. As in the stratosphere, concentration peaks are at lower altitudes than VMR peaks, however, altitude difference 
is 3 times less: $5 \mathrm{~km}$ (between $90 \mathrm{~km}$ and $95 \mathrm{~km}$; dashed lines in Fig. 5, right and left, respectively) compared to $15 \mathrm{~km}$ in Fig. 4 (right and left). The altitude difference in the simulated secondary ozone maximum is also relatively small and on global average, the ozone maximum in the mesopause region is higher in VMR than in number density by 2-4 km [60].

Figure 5 shows that no significant regional difference in timing and intensity of the SAO maxima (top and middle panels) in both VMR (left) and concentration (right). SAO in zonal mean (lower panel in Fig. 5) is practically indistinguishable from the regional ones (top and middle panels).

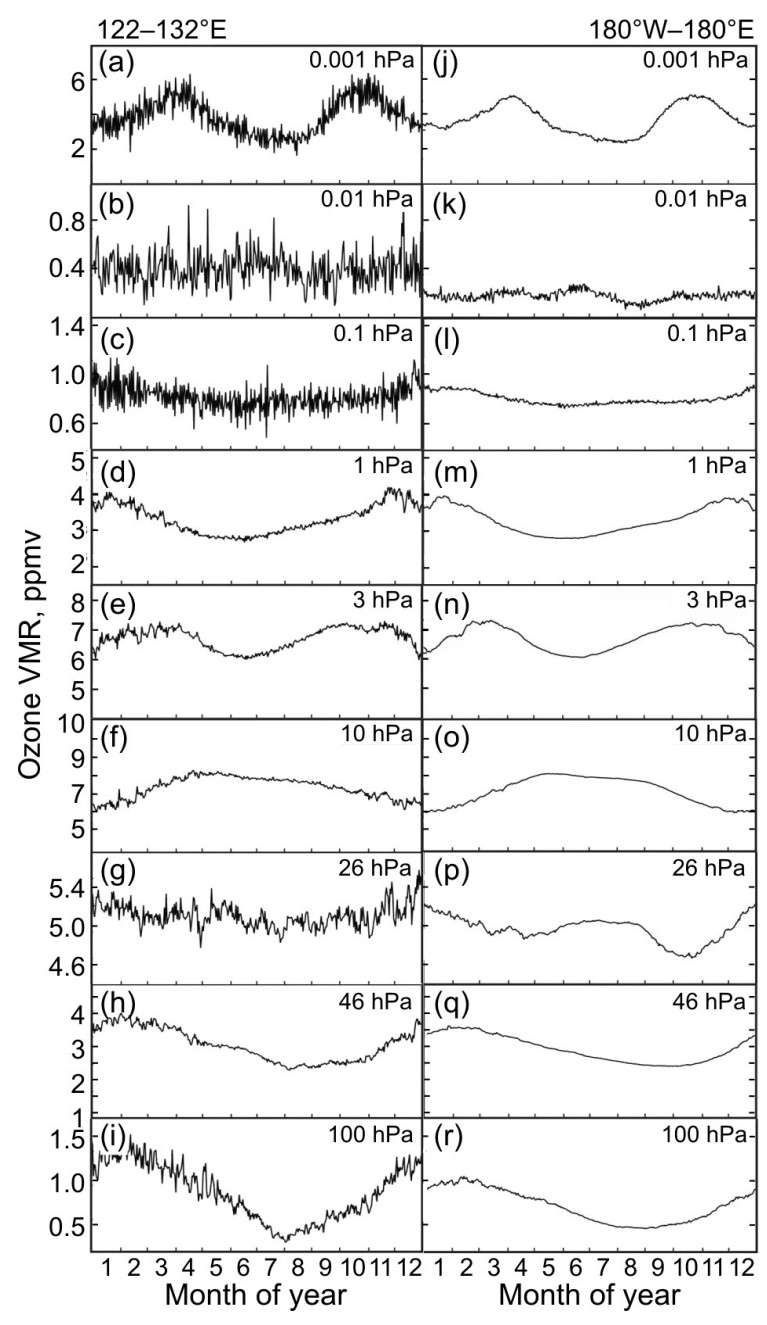

Figure 6. Annual cycle in the ozone VMR at 9 pressure levels in the stratosphere and mesosphere according to the MLS measurements.

The geopotential and ozone in the mesosphere have more frequent longitudinal oscillation compared to the QSW1 pattern in the stratosphere (Fig. 2a and Fig. 3a). Besides, the SAO shape in the ozone VMT at $0.001 \mathrm{hPa}$ (the mesopause region) only slightly similar to that at $1 \mathrm{hPa}$ and $3 \mathrm{hPa}$ (upper stratosphere-stratopause region) and 
differs in the time and clarity of the maxima (Fig. 6). The difference in the SAO peaks at altitudes $30-60 \mathrm{~km}$ and $80-100 \mathrm{~km}$ was noted in [56]. The differences in the QSW structure and SAO evolution suggest uncoupling between the stratosphere and mesosphere in wave sources and ozone photochemistry. This suggestion is in agreement with the results [61] that the SAO components of ozone and temperature are consistently in phase above about $80 \mathrm{~km}$ and are mostly out of phase with each other between about 35 and $80 \mathrm{~km}$. Therefore, the ozone production-loss chains above and below $\sim 80 \mathrm{~km}$ may be different in their spatio-temporal patterns. A noted in [60], the very low temperatures at the mesopause accelerate the formation of ozone and inhibit the loss.

About the waves in the mesosphere, breaking gravity waves that have been filtered by planetary-scale wind variations below, act to generate planetary waves in the middle and upper mesosphere [62]. The QSW can be generated in situ in the mesosphere by longitudinally variable gravity wave drag and by flow instabilities at mid-latitudes [15]. Hence, the mesospheric wave sources, as being independent on the stratospheric ones, can contribute to the observed differences in the QSW patterns in geopotential height and ozone (Fig. 2 and Fig. 3).

The SAO differences in the upper stratosphere and mesopause region could be preliminary attributed to distinctions in temperature-dependent ozone photochemistry $[60,61,55]$, however, this aspect of annual ozone variation needs additional analysis.

As in the stratosphere, concentration peaks are at lower altitudes than VMR peaks, however, altitude difference is 3 times less: $5 \mathrm{~km}$ (between $90 \mathrm{~km}$ and $95 \mathrm{~km}$; dashed lines in Fig. 5, right and left, respectively) compared to $15 \mathrm{~km}$ in Fig. 4 (right and left). The altitude difference in the simulated secondary ozone maximum is also relatively small and on global average, the ozone maximum in the mesopause region is higher in VMR than in number density by $2-4 \mathrm{~km}[60]$.

\section{Conclusions}

Based on the Aura MLS data, we have analyzed the altitudinal changes in the QSW structure and ozone annual cycle in the $\mathrm{NH}$ mid-latitudes $40-50^{\circ} \mathrm{N}$. The altitude range between the tropopause $(316 \mathrm{hPa}, 8 \mathrm{~km})$ and mesopause $(0.001 \mathrm{hPa}, 96 \mathrm{~km})$, winter months January-February and decade 2011-2020 are covered in this study. The analysis is focused on the region of the zonal maximum in total ozone over Aleutian Low. The longitude segment $122-132^{\circ} \mathrm{E}$, centered on Longfengshan, China, is examined more carefully.

The QSW westward phase tilt with altitude is clearly represented in the structure of geopotential height along the zone $40-50^{\circ} \mathrm{N}$. Wave 2 (QSW2) in the lower stratosphere transforms into wave 1 (QSW1) in the upper stratosphere-stratopause region, where the QSW1 ridge (trough) extends to the eastern (western) longitudes. We point out that due to the westward phase tilt there is an association of the North American High in the troposphere (at $\sim 120^{\circ} \mathrm{W}$ ) with the QSW1 ridge in the stratosphere, known as the Aleutian anticyclone. This association is broadly consistent with other works, but has 
not been specifically noted previously. The tropospheric Aleutian low itself $\left(\right.$ at $\left.\sim 180^{\circ} \mathrm{E}\right)$ is projected onto the QSW1 trough in the western hemisphere stratosphere.

Zonal anomalies in ozone are associated with the tropospheric centers of action only in the lower stratosphere (QSW2-type structure), but do not show regular westward tilt towards the upper levels. The formation of the QSW structure in ozone of middle-upper stratosphere requires a more detailed analysis with better vertical resolution.

Using two units, volume mixing ratio and concentration, changes of the annual ozone cycle with altitude between the stratosphere and mesosphere were carefully compared for the first time. The ozone maximum in the vertical profile lies higher in VMR than in concentration by about $15 \mathrm{~km}(5 \mathrm{~km})$ in the stratosphere (mesosphere), in consistency with earlier studies. We found that the properties of the annual cycle are better resolved just in the altitude range of the main ozone maximum: middle-upper stratosphere in VMR and lower stratosphere in concentration. Both approaches reveal $\mathrm{SAO} / \mathrm{AO}-$ related changes in the of ozone peak altitudes in a range of 4-6 km during the year.

The VMR time-altitude section shows the transition from the summer ozone maximum in the middle stratosphere $(10 \mathrm{hPa})$ to semi-annual oscillation in the upper stratosphere-stratopause region $(3 \mathrm{hPa}$ and $1 \mathrm{hPa})$. SAO maxima appear in spring and autumn at $3 \mathrm{hPa}$ and shift to the winter months above, at $1 \mathrm{hPa}$, whereas summer minimum replaces the $10-\mathrm{hPa}$ summer maximum. The altitudinal transition from summer maximum to summer minimum of ozone likely displays dominance of photochemical ozone production at $30-40 \mathrm{~km}$ and ozone depletion due to the temperature-dependent photochemistry at 40-50 $\mathrm{km}$ [23,55,58,59]. However, the conditions of the formation of both SAO and summer maximum-to-minimum transition in closely adjacent layers of the stratosphere in the zone $40-50^{\circ} \mathrm{N}$ require clarification in future studies involving theory, models and independent observations.

The time-altitude section and time series of ozone in the lower stratosphere show the well-known winter-spring maximum and late-summer-autumn minimum. In the Longfengshan domain, the earliest development of the annual cycle among the midlatitude regions with maximum ozone in February and minimum ozone in August displays the influence of the QSW structure and is in general agreement with other works. The specificity of AO here depends on the relationship between the rates of the processes of dynamical ozone accumulation (autumn-winter) and photochemical relaxation (spring-summer) in the region of the quasi-stationary maximum of total ozone. Unlike VMR, SAO is barely noticeable in the upper-stratospheric concentration.

The "no-annual-cycle" boundary between the dynamically controlled lower stratosphere and the chemically controlled middle-upper stratosphere was found. It is at a VMR level of 5 ppmv at an altitude of about $25 \mathrm{~km}$. A similar absence of a noticeable annual ozone cycle exists in the mesospheric layer with a VMR of 0.2-0.9 ppmv between the SAOs in the upper stratosphere and in the mesopause region. These atmospheric layers with undisturbed ozone VMR throughout the year are of interest for future research. 
The differences in the QSW structure and SAO evolution between the stratosphere and mesosphere-mesopause region found in this work suggest uncoupling in wave sources and changes in ozone. The QSW can be generated in situ in the mid-latitude mesosphere $[15,62]$ independently on the stratospheric ones formed due to propagation from the troposphere. The SAO differences in the upper stratosphere and mesopause region could be preliminary attributed to distinctions in temperature-dependent ozone photochemistry $[55,60,61]$. However, these comparisons need to be made on a larger observational base and with the use of chemistry-climate modeling.

Author Contributions: Conceptualization, O.E. and G.M.; methodology, O.E. and Y.S.; data acquisition, C.Z., and O.E.; software, Y.A., C.Z. and O.E.; validation, O.E., Y.S. and G.M.; investigation, O.E., G.M., Y.A., and C.Z.; writing-original draft preparation, O.E., and G.M.; writing-review and editing, O.E., C.Z., Y.S., G.M., Y.A., and V.S.; visualization, O.E., and C.Z.; supervision, G.M.; project administration, G.M., V.S. and W.H. Each author contributed to the interpretation and discussion of the results and edited the manuscript. All authors have read and agreed to the published version of the manuscript.

Funding: This research received no external funding.

Acknowledgments: This work was partially supported by the College of Physics, International Center of Future Science, Jilin University, China, and by the Ministry of Education and Science of Ukraine with the grant BN-06 for prospective development of a scientific direction "Mathematical sciences and natural sciences" and the project 20BF051-02 at Taras Shevchenko National University of Kyiv. This work contributed to the National Antarctic Scientific Center of Ukraine research objectives. The Aura Microwave Limb Sounder (MLS) data were obtained from the Goddard Earth Sciences Data and Information Services Center.

Conflicts of Interest: The authors declare no conflict of interest.

\section{References}

1. Wirth, V. Quasi-stationary planetary waves in total ozone and their correlation with lower stratospheric temperature. J. Geophys. Res. 1998, 98, 8873-8882. doi:10.1029/92JD02820.

2. Gabriel, A.; Körnich, H.; Lossow, S.; Peters, D.H.W.; Urban, J.; Murtagh, D. Zonal asymmetries in middle atmospheric ozone and water vapour derived from Odin satellite data 2001-2010. Atmos. Chem. Phys. 2011, 11, 9865-9885. https://doi.org/10.5194/acp-11-9865-2011.

3. Wills, R.C.J.; White, R.H.; Levine X.J. Northern Hemisphere stationary waves in a changing climate. Curr. Clim. Change Rep. 2019, 5, 372-389. https://doi.org/10.1007/s40641-019-00147-6.

4. Charney, J.G., Drazin P.G. Propagation of planetary-scale disturbances from the lower into the upper atmosphere. J. Geophys. Res. 1961, 66, 83-109. doi:10.1029/JZ066I001P00083.

5. Stray, N.H.; Orsolini, Y.J.; Espy, P.J.; Limpasuvan, V.; Hibbins, R.E. Observations of planetary waves in the mesosphere-lower thermosphere during stratospheric warming events. Atmos. Chem. Phys. 2015, 15, 4997-5005. doi:10.5194/acp-15-4997-2015.

6. Matsuno, T. Vertical propagation of stationary planetary waves in the winter Northern Hemisphere. J. Atmos. Sci. 1970, 27, 871-883. https://doi.org/10.1175/1520-0469(1970)027<0871: VPOSPW>2.0.CO;2.

7. Hood, L.L.; Zaff, D.A. Lower stratospheric stationary waves and the longitude dependence of ozone trends in winter. J. Geophys. Res. 1995, 100, 25791-25800. https://doi.org/10.1029/95JD01943.

8. Wolf, G.; Brayshaw, D.J.; Klingaman, N.P.; Czaja, A. Quasi-stationary waves and their impact on European weather and extreme events. Q. J. R. Meteorol. Soc. 2018, 144, 2431-2448. https://doi.org/10.1002/qj.3310.

9. Eck, T.F.; Bhartia, P.K.; Kerr J.B. Satellite estimation of spectral UVB irradiance using TOMS derived total ozone and UV reflectivity. Geophys. Res. Lett. 1995, 22, 611-614. https://doi.org/10.1029/95GL00111.

10. Kazantzidis, A.; Bais, A.F.; Gröbner, J.; Herman, J.R.; Kazadzis, S.; Krotkov, N.; Kyrö, E.; den Outer, P.N.; Garane, K.; Görts, P.; Lakkala, K. Comparison of satellite-derived UV irradiances with ground-based measurements at four European stations. $J$. Geophys. Res. 2006, 111, D13207. doi:10.1029/2005JD006672.

11. Kim, J.; Cho, H.-K.; Mok, J.; Yoo, H.D.; Cho, N.S. Effects of ozone and aerosol on surface UV radiation variability. J. Photochem. Photobiol. B: Biol. 2013, 119, 461-451. https://doi.org/10.1016/j.jphotobiol.2012.11.007.

12. Garfinkel, C.I.; White, I.; Gerber, E.P.; Son, S.-W.; Jucker, M. Stationary wave and surface radiative effects weaken and delay the near-surface response to stratospheric ozone depletion. Earth and Space Science Open Archive 2021, 40 p., doi:10.1002/essoar.10508684.1. 
13. Fountoulakis, I.; Diémoz, H.; Siani, A.M.; di Sarra, A.; Meloni, D.; Sferlazzo, D.M. Variability and trends in surface solar spectral ultraviolet irradiance in Italy: on the influence of geopotential height and lower-stratospheric ozone. Atmos. Chem. Phys. 2021, 21, 18689-18705. https://doi.org/10.5194/acp-21-18689-2021.

14. Huang, F.T.; Mayr, H.G.; Russell III, J.M.; Mlynczak, M.G. Ozone and temperature decadal trends in the stratosphere, mesosphere and lower thermosphere, based on measurements from SABER on TIMED. Ann. Geophys. 2014, 32, 935-949. doi:10.5194/angeo-32-935-2014.

15. Matthias, V.; Ern, M. On the origin of the mesospheric quasi-stationary planetary waves in the unusual Arctic winter 2015/2016. Atmos. Chem. Phys. 2018, 18, 4803-4815. https://doi.org/10.5194/acp-18-4803-2018.

16. Efstathiou, M.N.; Varotsos, C.A.; Singh, R.P.; Cracknell, A.P.; Tzanis, C. On the longitude dependence of total ozone trends over middle-latitudes. Int. J. Remote Sens. 2003, 24, 1361-1367, doi:10.1080/0143116021000044814.

17. Nikulin, G.; Karpechko, A. The mean meridional circulation and midlatitude ozone buildup. Atmos. Chem. Phys. 2005, 5, 31593172. https://doi.org/10.5194/acp-5-3159-2005.

18. Peters, D.H.W.; Gabriel, A.; Entzian, G. Longitude-dependent decadal ozone changes and ozone trends in boreal winter months during 1960-2000. Ann. Geophys. 2008, 26, 1275-1286. https://doi.org/10.5194/angeo-26-1275-2008/.

19. Demirhan Bari, D.; Gabriel, A.; Körnich, H.; Peters, D.W.H. The effect of zonal asymmetries in the Brewer-Dobson circulation on ozone and water vapor distributions in the northern middle atmosphere. J. Geophys. Res. Atmos., 2013, 118, 3447-3466. doi:10.1029/2012JD017709, 2013.

20. Waugh, D.W.; Randel, W.J. Climatology of Arctic and Antarctic polar vortices using elliptical diagnostics. J. Atmos. Sci. 1999, 56, 1594-1613. https://doi.org/10.1175/1520-0469(1999)056<1594:COAAAP>2.0.CO;2.

21. Grytsai, A.V.; Evtushevsky, O.M.; Agapitov, O.V.; Klekociuk, A.R.; Milinevsky, G.P. Structure and long-term change in the zonal asymmetry in Antarctic total ozone during spring. Ann. Geophys. 2007, 25, 361-374. doi:10.5194/angeo-25-361-2007.

22. Salby, M.L.; Callaghan, P.F. Interannual changes of the stratospheric circulation: relationship to ozone and tropospheric structure. J. Clim. 2002, 15, 3673-3685. https://doi.org/10.1175/1520-0442(2003)015<3673:ICOTSC>2.0.CO;2.

23. Sekiguchi, Y.; Kida, H. The seasonal variation of total ozone amount in middle latitudes. J. Meteorol. Soc. Japan 1971, 49, 95110. https://doi.org/10.2151/jmsj1965.49.2_95.

24. Rieder, H.E.; Jancso, L.M.; Di Rocco, S.; Staehelin, J.; Maeder, J.A.; Peter, T.; Ribatet, M.; Davison, A.C.; De Backer, H.; Koehler, U.; Krzyścin, J.; Vaníček, K. Extreme events in total ozone over the Northern mid-latitudes: an analysis based on long-term data sets from five European ground-based stations. Tellus B 2011, 63, 860-874. doi:10.1111/j.1600-0889.2011.00575.x.

25. Bowman, K.P.; Krueger, A.J. A global climatology of total ozone from the Nimbus 7 total ozone mapping spectrometer. J. Geophys. Res. 1985, 90, 7967-7976. https://doi.org/10.1029/JD090iD05p07967.

26. Fioletov, V.E.; Shepherd, T.G. Seasonal persistence of midlatitude total ozone anomalies. Geophys. Res. Lett. $2003,30,1417$. doi:10.1029/2002GL016739.

27. Miyazaki, K.; Iwasaki, T.; Shibata, K.; Deushi, M. Roles of transport in the seasonal variation of the total ozone amount. J. Geophys. Res. 2005, 110, D18309. doi:10.1029/2005JD005900.

28. Tegtmeier, S.; Fioletov, V.E.; Shepherd, T.G. A global picture of the seasonal persistence of stratospheric ozone anomalies. J. Geophys. Res. 2010, 115, D18119. doi:10.1029/2009JD013010.

29. Coldewey-Egbers, M.; Loyola, D.G.; Labow, G.; Frith, S.M. Comparison of GTO-ECV and adjusted MERRA-2 total ozone columns from the last 2 decades and assessment of interannual variability. Atmos. Meas. Tech. 2020, 13, $1633-1654$. https://doi.org/10.5194/amt-13-1633-2020.

30. Krzyścin, J.W.; Rajewska-Więch, B.; Jarosławski, J. The long-term variability of atmospheric ozone from the 50-yr observations carried out at Belsk (51.84 ${ }^{\circ}$, 20.78 ${ }^{\circ}$ ). Poland. Tellus B 2013, 65, 21779, https://doi.org/10.3402/tellusb.v65i0.21779.

31. Eleftheratos, K.; Kouklaki, D.; Zerefos, C. Sixteen years of measurements of ozone over Athens, Greece with a Brewer spectrophotometer. Oxygen 2021, 1, 32-45. https://doi.org/10.3390/oxygen1010005.

32. Iwasaki, T.; Kaneto, S. Photochemical and dynamical contributions to the seasonal variation of total ozone amount over Japan. J. Meteorol. Soc. Japan, 1984, 62, 343-356. https://doi.org/10.2151/jmsj1965.62.2_343.

33. Antón, M.; Bortoli, D.; Costa, M.J.; Kulkarni. P.S.; Domingues, A.F.; Barriopedro, D.; Serrano, A.; Silva, A.M. Temporal and spatial variabilities of total ozone column over Portugal. Remote Sens. Environ. 2011, 115, 855-863. doi:10.1016/j.rse.2010.11.013.

34. Zou, H.; Zhou, L.; Gao, Y.; Chen, X.; Li, P.; Ji, C.; Ma, S.; Gao, D. Total ozone variation between $50^{\circ}$ and $60^{\circ} \mathrm{N}$. Geophys. Res. Lett. 2005, 32, L23812. doi:10.1029/2005GL024012.

35. Evtushevsky, O.; Grytsai, A.; Milinevsky, G. On the regional distinctions in annual cycle of total ozone in the northern midlatitudes. Remote Sensing Letters 2014, 5, 205-212. http://dx.doi.org/10.1080/2150704X.2014.894653.

36. Zhang, J.; Tian, W.; Xie, F.; Sang, W.; Guo, D.; Chipperfield, M.; Feng, W.; Hu, D. Zonally asymmetric trends of winter total column ozone in the northern middle latitudes. Clim. Dyn. 2019, 52, 4483-4500. https://doi.org/10.1007/s00382-018-4393-y.

37. Livesey, N.J.; Read, W.G.; Wagner, P.A.; Froidevaux, L.; Lambert, A.; Manney, G. L.; Millán Valle, L.F.; Pumphrey, H.C.; Santee, M.L.; Schwartz, M.J.; et al. EOS MLS version 4.2x-3.1 Level 2 data quality and description document, Tech. rep., Jet Propulsion Laboratory, 2018, available from https://mls.jpl.nasa.gov/data/v4-2_data_quality_document.pdf.

38. Xu, X.; Manson, A.H.; Meek, C.E.; Chshyolkova, T.; Drummond, J.R.; Hall, C.M.; Riggin, D.M.; Hibbins, R.E. Vertical and interhemispheric links in the stratosphere-mesosphere as revealed by the day-to-day variability of Aura-MLS temperature data. Ann. Geophys. 2009, 27, 3387-3409. https://doi.org/10.5194/angeo-27-3387-2009. 
39. Schwartz, M.; Livesey, N.; Read, W. MLS/Aura Level 2 Geopotential Height V004, Greenbelt, MD, USA, Goddard Earth Sciences Data and Information Services Center (GES DISC) 2015a. Available online: https://disc.gsfc.nasa.gov/datasets/ML2GPH_004/summary/ (accessed on 09 February 2022).

40. Schwartz, M.; Froidevaux, L.; Livesey, N.; Read, W. (2015b), MLS/Aura Level 2 Ozone (O3) Mixing Ratio V004, Greenbelt, MD, USA, Goddard Earth Sciences Data and Information Services Center (GES DISC) 2015b, 10.5067/Aura/MLS/DATA2017. Available online: https://disc.gsfc.nasa.gov/datasets/ML2O3_004/summary/ (accessed on 15 December 2021).

41. Wang, Y.; Shulga, V.; Milinevsky, G.; Patoka, A.; Evtushevsky, O.; Klekociuk, A.; Han, W.; Grytsai, A.; Shulga, D.; Myshenko, V.; Antyufeyev, O. Winter 2018 major sudden stratospheric warming impact on midlatitude mesosphere from microwave radiometer measurements. Atmos. Chem. Phys. 2019, 19, 10303-10317. https://doi.org/10.5194/acp-19-10303-2019.

42. Shi, Y.; Shulga, V.; Ivaniha, O.; Wang, Y.; Evtushevsky, O.; Milinevsky, G.; Klekociuk, A.; Patoka, A.; Han, W.; Shulga, D. Comparison of major sudden stratospheric warming impacts on the mid-latitude mesosphere based on local microwave radiometer CO observations in 2018 and 2019. Remote Sens. 2020, 12, 3950. doi:10.3390/rs12233950.

43. Hoinka, K.P. Statistics of the global tropopause pressure. Mon. Wea. Rev. 1998, 126, 3303-3325. https://doi.org/10.1175/15200493(1998)126<3303:SOTGTP>2.0.CO;2.

44. Harvey, V.L.; Hitchman M.H. A climatology of the Aleutian High. J. Atmos. Sci. 1996, 53, 2088-2102. doi:10.1175/15200469(1996)053<2088:ACOTAH>2.0.CO;2.

45. Kosaka, Y.; Nakamura, H. Mechanisms of meridional teleconnection observed between a summer monsoon system and a subtropical anticyclone. Part I: The Pacific-Japan pattern. J. Clim. 2010, 23, 5085-5108. doi:10.1175/2010JCLI3413.1.

46. Sugita, T.; Nakajima, H.; Yokota, T.; Kanzawa, H.; Gernandt, H.; Herber, A.; von der Gathen, P.; König-Langlo, G.; Sato, K.; Dorokhov, V.; et al. Ozone profiles in the high-latitude stratosphere and lower mesosphere measured by the Improved Limb Atmospheric Spectrometer (ILAS)-II: Comparison with other satellite sensors and ozonesondes. J. Geophys. Res. 2006, 111, D11S02. doi:10.1029/2005JD006439.

47. Boville B.W. The Aleutian stratospheric anticyclone. J. Atmos. Sci. 1960, 17, 329-336. https://doi.org/10.1175/15200469(1960)017<0329:TASA>2.0.CO;2.

48. France J.A.; Harvey V.L.; Randall C.E.; Hitchman M H.; Schwartz M.J. A climatology of stratopause temperature and height in the polar vortex and anticyclones. J. Geophys. Res. 2012, 117, D06116, doi:10.1029/2011JD016893.

49. Serreze, M.C.; Carse, F.; Barry R.G.; Rogers, J.C. Icelandic Low cyclone activity: climatological features, linkages with the NAO, and relationships with recent changes in the Northern Hemisphere circulation. J. Clim. 1997, 10, 453-464. https://doi.org/10.1175/1520-0442(1997)010<0453:ILCACF>2.0.CO;2.

50. Nigam, S.; DeWeaver, E. Stationary waves (orographic and thermally forced). In: Encyclopedia of Atmospheric Sciences. Editor-In-Chief: James R. Holton; Editors: John Pyle and Judith A. Curry; Academic Press, Elsevier Science, London, 2003, 21212137. http://dx.doi.org/10.1016/B978-0-12-382225-3.00381-9.

51. Volodin, E.M.; Schmitz G. A troposphere-stratosphere-mesosphere general circulation model with parameterization of gravity waves: climatology and sensitivity studies. Tellus A: Dynamic Meteorology and Oceanography 2001, 53, 300-316. doi:10.3402/tellusa.v53i3.12191.

52. France, J.A.; Harvey, V.L.; Randall, C.E.; Collins, R.L.; Smith, A.K.; Peck, E.D.; Fang X. A climatology of planetary wavedriven mesospheric inversion layers in the extratropical winter. J. Geophys. Res. Atmos. 2015, 120, 399-413, doi:10.1002/2014JD022244.

53. Smith, A.K. Stationary planetary waves in upper mesospheric winds. J. Atmos. Sci. 1997, 54, $2129-2145$. https://doi.org/10.1175/1520-0469(1997)054<2129:SPWIUM>2.0.CO;2.

54. Maeda, K. Annual and semiannual oscillations of stratospheric ozone. Pure Appl. Geophys. 1987, 125, 147-165. https://doi.org/10.1007/BF00878619.

55. Moreira, L.; Hocke, K.; Navas-Guzmán, F.; Eckert, E.; von Clarmann, T.; Kämpfer, N. The natural oscillations in stratospheric ozone observed by the GROMOS microwave radiometer at the NDACC station Bern. Atmos. Chem. Phys. 2016, 16, 1045510467. doi:10.5194/acp-16-10455-2016.

56. Joshi, V.; Sharma, S.; Kumar, K.N.; Patel N.; Kumar P.; Bencherif H.; Ghosh P.; Jethva C.; Vaishnav R. Analysis of the middle atmospheric ozone using SABER observations: a study over mid-latitudes in the northern and southern hemispheres. Clim. Dyn. 2020, 54, 2481-2492. doi:10.1007/s00382-020-05124-6.

57. Dütsch, H.U. The ozone distribution in the atmosphere. Can. J. Chem. 1974, 52, 1491-1504. https://doi.org/10.1139/v74-220.

58. Prather, M.J. Ozone in the upper stratosphere and mesosphere. J. Geophys. Res. 1981, 86, 5325-5338. doi:10.1029/jc086ic06p05325.

59. Tummon, F.; Hassler, B.; Harris, N.R.P.; Staehelin, J.; Steinbrecht, W.; Anderson, J.; Bodeker, G.E.; Bourassa, A.; Davis, S.M.; Degenstein, D.; et al. Intercomparison of vertically resolved merged satellite ozone data sets: interannual variability and longterm trends. Atmos. Chem. Phys. 2015, 15, 3021-3043. https://doi.org/10.5194/acp-15-3021-2015.

60. Smith, A.K.; Marsh D.R. Processes that account for the ozone maximum at the mesopause. J. Geophys. Res. 2005, 110, D23305. doi:10.1029/2005JD006298.

61. Huang, F.T.; Mayr, H.G.; Reber, C.A.; Russell III, J.M.; Mlynczak, M.G.; Mengel J.G. Ozone quasi-biennial oscillations (QBO), semiannual oscillations (SAO), and correlations with temperature in the mesosphere, lower thermosphere, and stratosphere, based on measurements from SABER on TIMED and MLS on UARS. J. Geophys. Res. 2008, 113, A01316. doi:10.1029/2007JA012634. 
62. Smith, A.K. The Origin of Stationary Planetary Waves in the Upper Mesosphere. Journal of the Atmospheric Sciences 2003, 60, 3033-3041. doi: https://doi.org/10.1175/1520-0469(2003)060<3033:TOOSPW>2.0.CO;2. 